\section{Original Research}

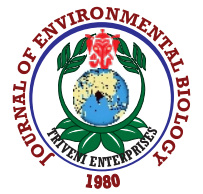

DOI : http://doi.org/10.22438/jeb/41/2(SI)/JEB-02
Journal Home page : www.jeb.co.in ^ E-mail : editor@jeb.co.in Journal of Environmental Biology

p-ISSN: 0254-8704 e-ISSN: $2394-0379$ CODEN: JEBIDP
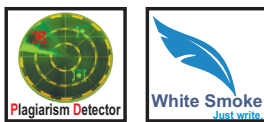

\title{
Avian diversity in Marudu Bay mangrove forest, Sabah, Malaysia
}

\author{
M.N. Rajpar', S. Gücel', S. Ullah', A. Ullah', M. Saad', A.B.H. Aboushiba ${ }^{5}$, C.O. Martin ${ }^{6}$ and M. Zakaria ${ }^{6_{*}^{*}}$ \\ 'Department of Forestry, Shaheed Benazir Bhutto University Sheringal Dir (Upper), Khyber Pakhtunkhwa, 18050, Pakistan \\ ${ }^{2}$ Near East University, Environmental Research Center, Nicosia, 99138, Northern Cyprus \\ ${ }^{3}$ Department of Agricultural Extension Education and Communication, The University of Agriculture, Peshawar, 25120, Pakistan \\ ${ }^{4}$ Department of Forestry and Wildlife Management, The University of Haripur, 22620, Pakistan \\ ${ }^{5}$ Department of Zoology, Faculty of Science, University of Sebha, 18758, Libya \\ ${ }^{6}$ Faculty of Forestry, Universiti Putra Malaysia, Serdang, Selangor, 43400, Malaysia \\ *Corresponding Author Email : mzakaria@upm.edu.my
}

\section{Abstract}

Aim: Avian species diversity along the rivers of Sungai Bungon Mati (SBM), Sungai Supitan (SSU) and Sungai Sat (SSA) in the Marudu Bay Mangrove Forest, Sabah, Malaysia was investigated.

Methodology: Transect survey method was used to study avian species diversity from March to May, 2009 and February, 2010.

Results : From 800 bird observations, a total of 69 species belonging to 28 families were recorded. SBM was heavily crowded by 44 avian species from 25 families $(41.0 \%$ of all detections). In SSU, 43 species from 25 families $(29.3 \%)$ and in SSA32 species from 19 families (29.6\%) were recorded.

Interpretation : Diversity analysis indicated that SBM was more diverse and evenly distributed than the other two river systems. The occurrence of mudflats, shallow water, richness of food and dense vegetation were important factors affecting the richness and diversity of water birds as well as terrestrial or open country birds.

Key words : Avian diversity, Mangrove, Sabah, Species richness, Transect survey

How to cite : Rajpar, M.N., S. Gücel, S. Ullah, A. Ullah, M. Saad, A.B.H. Aboushiba, C.O. Martin and M. Zakaria: Avian diversity in Marudu Bay mangrove forest, Sabah, Malaysia. J. Environ. Biol., 41, 285-292 (2020). 


\section{Introduction}

A mangrove forest is a type of vegetation that grows in transitional zones along sheltered coastal, estuarine and riverine areas where rivers drain into the sea, such as estuaries in the tropics and subtropics (FAO 2007, Faridah-Hanum et al., 2012). It consists of waterways (estuaries, creeks, canals, lagoons and backwaters), mudflats, salt pans and islands (Kjerfve, 1990). Globally, mangrove forests cover an area of $137,760 \mathrm{~km}^{2}$, occurring in tropical and subtropical areas of 118 countries (Giri et al., 2011). The highest percentage of mangrove forests is distributed between latitude $5^{\circ} \mathrm{N}$ and $5^{\circ} \mathrm{S}, 32^{\circ} \mathrm{N}$ and longitude $38^{\circ} \mathrm{E}$ (Friess et al., 2012), occurring in Asia (42.0\%), Africa (21.0\%), North/Central America (5.0\%), Oceania (12.0\%) and South America (11.0\%) (Giri et al., 2011).

Nearly $12 \%$ of the mangrove forests in SoutheastAsia are confined to Malaysia. Out of 577,500 ha of mangrove forests in Malaysia, $59 \%$ occur in Sabah (341,000 ha), 23\% in Sarawak $(132,000$ ha) and $18 \%$ in Peninsular Malaysia (104,200 ha) (Aizpuru et al., 2000; SFD, 2008; Faridah-Hanum et al., 2012). In Sabah, 93.0\% percent of these have been declared as a Permanent Forest Reserve under the Forest EnactmentAct 1968 (SFD, 2008).

Mangrove forests are highly productive habitats, due to the richness of food resources and diversity of vegetation, in addition offering suitable habitats for a variety of faunal species (Rajpar and Zakaria, 2011). They support a variety of marine, freshwater and terrestrial wildlife species, i.e., birds, fishes, reptiles, mammals and aquatic invertebrate species. Unfortunately, mangrove forests around the world are declining at an alarming rate due to human interventions such as over exploitation for fuel wood and fodder, urbanization, agricultural fields and aquaculture (Upadhyay et al., 2002, Barbier and Cox, 2004; Mineau et al., 2005; Upadhyay et al., 2002). In addition, the rapid decrease in water flow from rivers due to the construction of water reservoirs, dumping of domestic and industrial sewage and reclamation of inter-tidal areas has severely affected the services and functions of mangrove habitats, which ultimately has had devastating effects on the occurrence and richness of different faunal species. There is an urgent need to protect the mangrove forests in order to reduce the pressure on different species inhabiting these fragile habitats. Species diversity reflects the relative abundance of species and indicates community structure shape and importance of particular habitats.

Avian species are the most conspicuous and significant components of wetland habitats (Githiru and Lens, 2006; Li and Mundkur, 2007; Rajpar and Zakaria, 2011). Species diversity and richness are crucial for the proper functioning and maintenance of ecosystem health i.e., each species play a significant role in ecosystem function. Each species has its own niche; they interact with each other and with the environment, thus performing various specific functions. The loss of species diversity and richness may affect the functioning of the ecosystem. Thus, monitoring the avian diversity and richness is a crucial tool for determining the importance of a particular habitat, population trends of avian species during specific periods and the current status of habitats for effective conservation and successful future management (DeSante et al., 2005). For this purpose, Distance Sampling is a widely used method to study animal populations including avian and mammal communities (Buckland et al., 1993; Bibby et al., 2000; Gregory et al., 2004) in a variety of habitats such as lakes (Aborn, 2007), forests (Lee and Marsden, 2008), and wetlands (Zakaria et al., 2009, Rajpar and Zakaria, 2011).

In Malaysia, information on avian richness and diversity in mangrove forests is scarce and no detailed study has been previously undertaken on the Marudu Bay Mangrove Forest, Sabah. However, a few studies have been carried out in other areas such as Klang Mangrove Forest, Selangor (Norhayati et al., 2009) and Matang Mangrove Forest, Perak (Wan Juliana et al., 2011), which only provide information covering the past few years. In view of the above, the present study aimed to identify the bird species richness and diversity inhabiting the Marudu Bay Mangrove forest Sabah, Malaysia, in order to establish baseline information to formulate future initiatives for future avian conservation and improved management.

\section{Materials and Methods}

Study area : This study was conducted in the Marudu Bay Mangrove Forest, Kota Marudu, Sabah due to its richness of vegetation, mudflats and food resources. The site is located between $6^{\circ} 15^{\prime \prime}$ to $6^{\circ} 45^{\prime \prime} \mathrm{N}$ latitude and $116^{\circ}$ to $117^{\circ} \mathrm{E}$ longitude and covers an area of 9550 ha. The study focused on three rivers, namely 'Sungai Bungon Mati' (SBM) 'Sungai Supitan' (SSU) and 'Sungai Sat' (SSA), due to the fact that they are easily accessible during low tides, the heterogeneity of vegetation, and the occurrence of soft submerged mud along the banks and estuarine areas (Fig. 1).

Bird surveys : Bird surveys were carried out by boat using the distance sampling method (point transect) (Buckland et al., 1993) during the periods $23^{\text {rd }}$ March to $3^{\text {rd }}$ April, $21^{\text {st }}$ to $27^{\text {th }}$ May, 2009 and $2^{\text {nd }}$ to $8^{\text {th }}$ February, 2010. A total of 60 observation points were established along the three rivers to cover the whole river area from downstream to upstream mangrove forest. The interval distance between each point station was $250 \mathrm{~m}$, which was set to avoid double counting of the same birds at more than one station.

Data analysis : Species Relative abundance (\%) of observed number of a particular species was divided by the total number of all observed bird species (Bibby et al., 2000). Avian diversity was analyzed using Community Analysis Package (PCA) Version 4.0 by Henderson and Seaby (2007). 


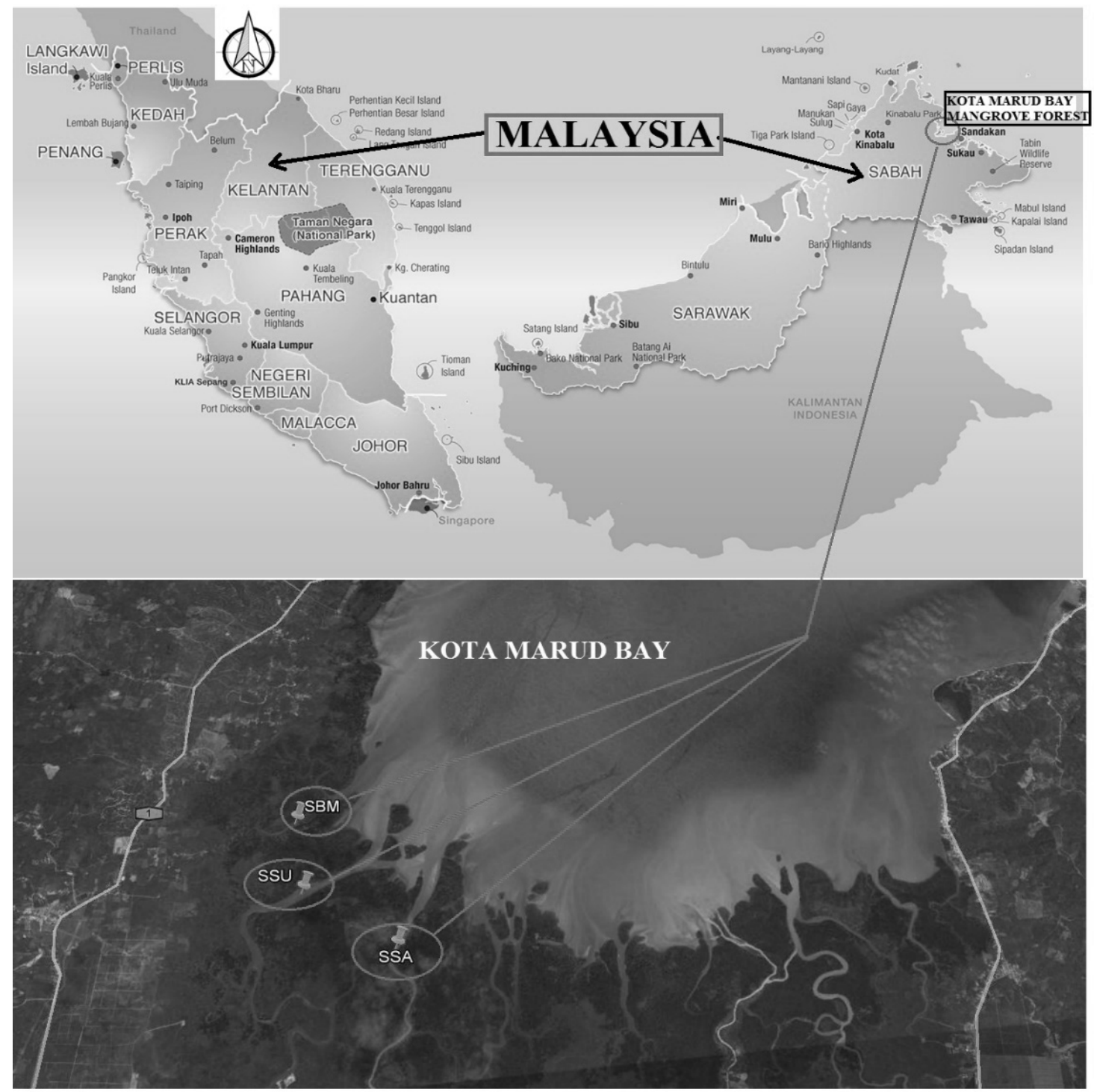

Fig. 1 : Location map of the Marudu Bay Mangrove forest Sabah, Malaysia.

Normality test : The Shapiro-Wilk normality test (Analytical Software version 8.1) by McGraw-Hill (2008) was used to check the reliability of data (Razali, 2011).

\section{Results and Discussion}

Bird families : A total of 28 bird families were recorded during the boat surveys (Table 1). The most dominant families were Ardeidae (12.0\% of all detections), Scolopacidae (10.3\%) and Picidae (8.6\%), while 16 other families were considered to be the rarest providing only one record each ( $1.7 \%$ each).

\section{Bird species composition}

Sungai Bungon Mati : Out of the total 328 bird observations
(41\% of all detections), 44 bird species from 25 families were detected, however, 14 bird species from the total recorded at Marudu Bay Mangrove Forest were absent.

Sungai Supitan : From a total 235 bird observations, 43 bird species from 25 families representing $29.3 \%$ of total detections were recorded, however, 15 species were not observed (Table 2).

Sungai Sat : Out of the total 237 bird observations, 32 species from 19 families (representing $29.6 \%$ of all detections) were recorded, however, 26 bird species were absent compared to the other two sites (Table 2).

The total record of 69 bird species (24 water birds representing $40.8 \%$ of all detections and 45 terrestrial birds 
Table 1: Bird families based on the number of species detected in Marudu Bay Mangrove Forest Sabah, Malaysia

\begin{tabular}{|c|c|c|c|c|c|c|c|}
\hline Family name & $\begin{array}{l}\text { Sungai } \\
\text { bungon mati }\end{array}$ & $\begin{array}{l}\text { Sungai } \\
\text { supitan }\end{array}$ & $\begin{array}{l}\text { Sungai } \\
\text { sat. }\end{array}$ & $\begin{array}{l}\text { Total number } \\
\text { of species }\end{array}$ & $\begin{array}{l}\text { Percentage } \\
(\%)\end{array}$ & $\begin{array}{l}\text { Total number of } \\
\text { bird individuals }\end{array}$ & $\begin{array}{l}\text { Percentage } \\
(\%)\end{array}$ \\
\hline Ardeidae & 3 & 7 & 5 & 7 & 12.08 & 112 & 14.00 \\
\hline Scolopacidae & 2 & 2 & 5 & 6 & 10.35 & 129 & 16.13 \\
\hline Picidae & 5 & 3 & 3 & 5 & 8.62 & 65 & 8.13 \\
\hline Cuculidae & 3 & 2 & 2 & 4 & 6.91 & 18 & 2.25 \\
\hline Nectariniidae & 3 & 3 & 1 & 4 & 6.91 & 22 & 2.75 \\
\hline Columbidae & 3 & 1 & 1 & 3 & 5.18 & 51 & 6.38 \\
\hline Alcedenidae & 3 & 3 & 3 & 3 & 5.18 & 74 & 9.25 \\
\hline Laniidae & 2 & 2 & 0 & 2 & 3.45 & 6 & 0.75 \\
\hline Accipitridae & 2 & 2 & 1 & 2 & 3.45 & 12 & 1.50 \\
\hline Sturnidae & 2 & 1 & 0 & 2 & 3.45 & 17 & 2.13 \\
\hline Turdidae & 2 & 2 & 1 & 2 & 3.45 & 19 & 2.38 \\
\hline Sylviidae & 1 & 2 & 0 & 2 & 3.45 & 37 & 4.63 \\
\hline Campephagidae & 0 & 1 & 0 & 1 & 1.72 & 1 & 0.13 \\
\hline Anhingidae & 0 & 1 & 1 & 1 & 1.72 & 2 & 0.25 \\
\hline Dicaeidae & 1 & 1 & 0 & 1 & 1.72 & 2 & 0.25 \\
\hline Hemiprocnidae & 1 & 1 & 0 & 1 & 1.72 & 3 & 0.38 \\
\hline Phalacrocoracidae & 0 & 0 & 1 & 1 & 1.72 & 3 & 0.38 \\
\hline Apodidae & 1 & 1 & 0 & 1 & 1.72 & 6 & 0.75 \\
\hline Muscicapidae & 1 & 1 & 1 & 1 & 1.72 & 10 & 1.25 \\
\hline Estrilidae & 1 & 0 & 1 & 1 & 1.72 & 11 & 1.38 \\
\hline Hirundinidae & 1 & 1 & 0 & 1 & 1.72 & 11 & 1.38 \\
\hline Psittacidae & 1 & 1 & 1 & 1 & 1.72 & 11 & 1.38 \\
\hline Artamidae & 1 & 1 & 0 & 1 & 1.72 & 15 & 1.88 \\
\hline Pachycephalidae & 1 & 0 & 1 & 1 & 1.72 & 16 & 2.00 \\
\hline Sittidae & 1 & 1 & 1 & 1 & 1.72 & 19 & 2.38 \\
\hline Timaliidae & 1 & 1 & 1 & 1 & 1.72 & 34 & 4.25 \\
\hline Rhipiduridae & 1 & 1 & 1 & 1 & 1.72 & 42 & 5.25 \\
\hline Chloropseidae & 1 & 1 & 1 & 1 & 1.72 & 52 & 6.50 \\
\hline TOTAL & 44 & 43 & 32 & 58 & 100 & 800 & 100 \\
\hline
\end{tabular}

representing 59.1\%) from 28 families indicated that Marudu Bay mangrove forest is a suitable habitat for a variety of bird species. They extensively utilized vegetated areas, and soft tidal mud banks, particularly along the banks of river and where rivers drain into the sea i.e., estuarine areas for foraging, resting and breeding purposes. The detection of higher numbers of species might be due to the richness and diversity of vegetation composition and structure (Rajpar and Zakaria, 2011; Faridah-Hanum et al., 2012; Hanum et al., 2013) such as the size and distribution of trees (Cueto and de Casenave, 1999); surrounding adjacent dry land vegetation (Leyequien et al., 2010), and availability of variety of food resources such as fishes, amphibians, reptiles and aquatic invertebrates. Furthermore, vegetation structure and diversity have created habitat heterogeneity, which has provided different niches and attracted a higher number of bird species (Black and Brennan, 1999).

The results indicated that the avian species in SBM were more diverse and evenly distributed as compared to other two sites. However, SSU was richer in bird species than SBM and SSA (Table 3). Wan Juliana et al. (2011) recorded 42 bird species in the Manjung Riparian Reserves, Perak, Peninsular Malaysia through direct observation whereas Norhayati et al. (2009) recorded 57 bird species from 26 families using direct observation and mist-netting in mangrove areas of the Klang Islands Forest Reserves, Selangor, Peninsular Malaysia. Noske (1995) recorded 47 bird species, excluding aerial hunters and waders in the west coast of Selangor, Peninsular Malaysia using fixed width transect whereas Sodhi et al., 1997 recorded 42 bird species using spot-mapping and 15 species captured with mist-nets in the mangrove forests of Singapore.

Records of wading birds such as herons, egrets, sandpipers, plovers, snipes, curlews, tattlers and shank species showed that intertidal mudflats are rich in aquatic plants and invertebrates, i.e., crustaceans (crabs, prawns), gastropods, polychaetes, bivalves, nematodes, insects and worms as reported by Cannicci et al. (2008) and Han (2011). Wading birds prefer to use soft mud exposed during low tides and shallow water areas for foraging due to prey availability and richness of food resources such as prawns and fishes (Lim et al., 2001; Manson et al., 2005), amphibians (Kruitwagen et al., 2007), nematodes (Netto and Gallucci, 2003), benthic invertebrates such as crabs, gastropods, bivalves and polychaetes (Lim et al., 2001; 


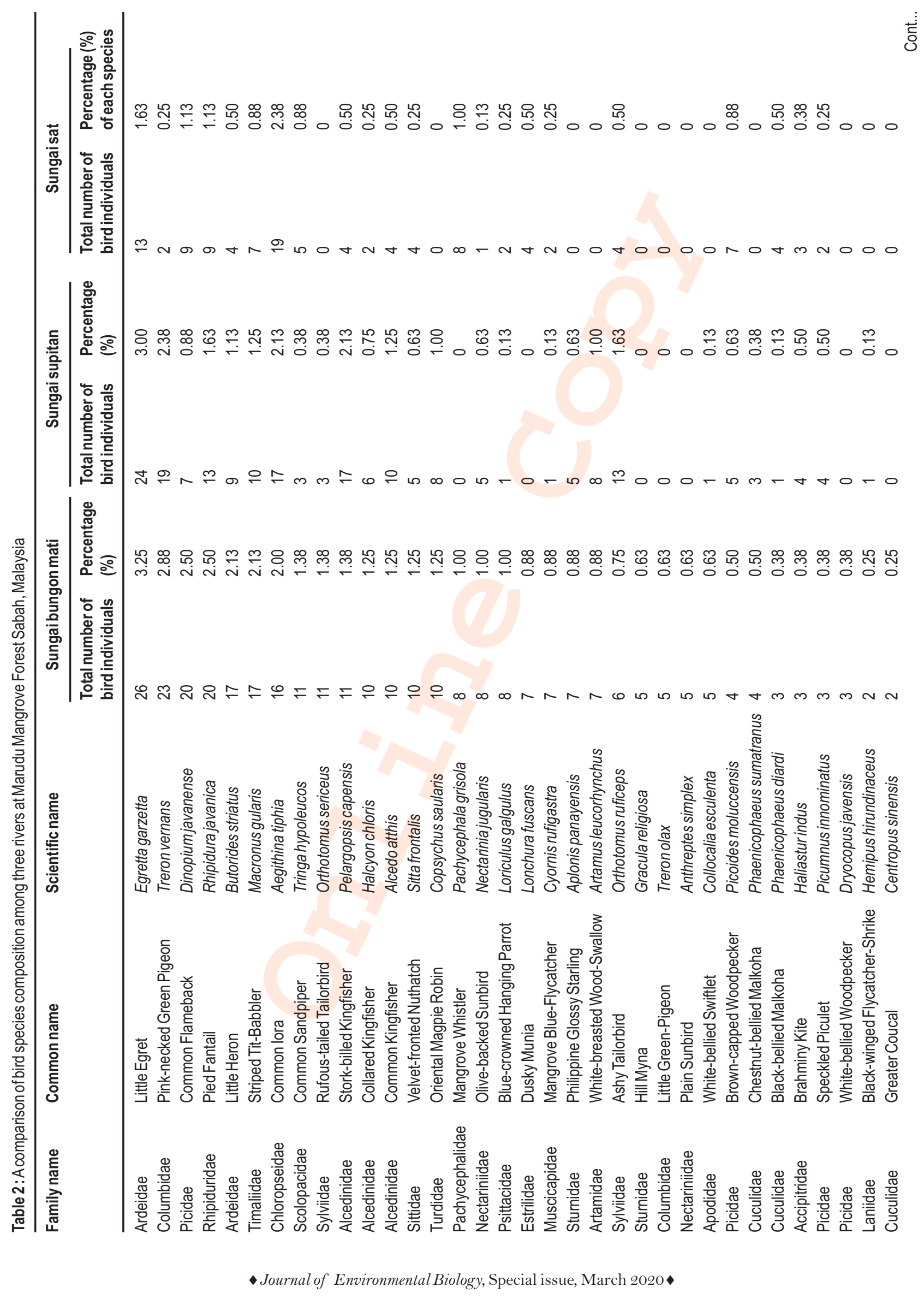




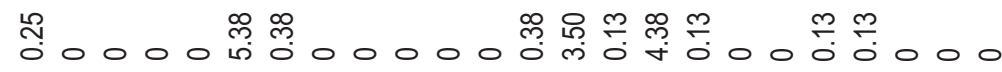

N 0000 P m 00000 m N r m - 0 O- - 000

ڤొ

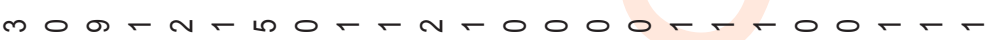

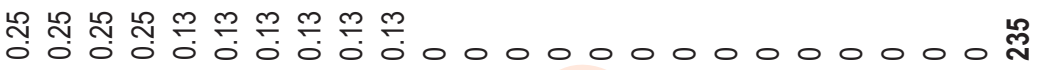

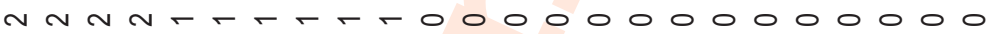

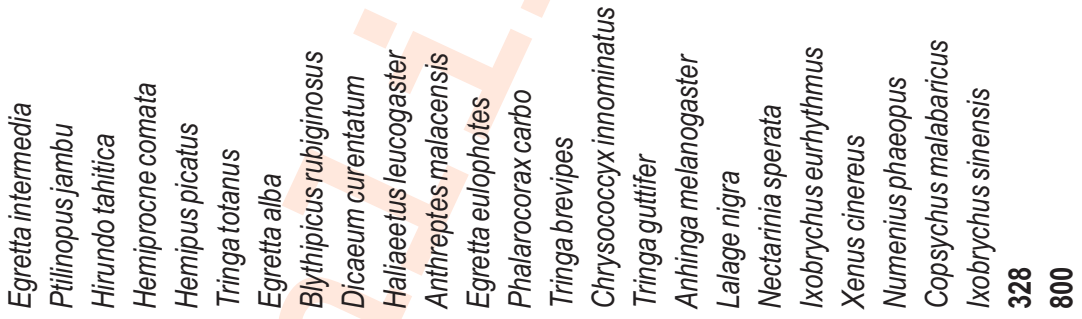

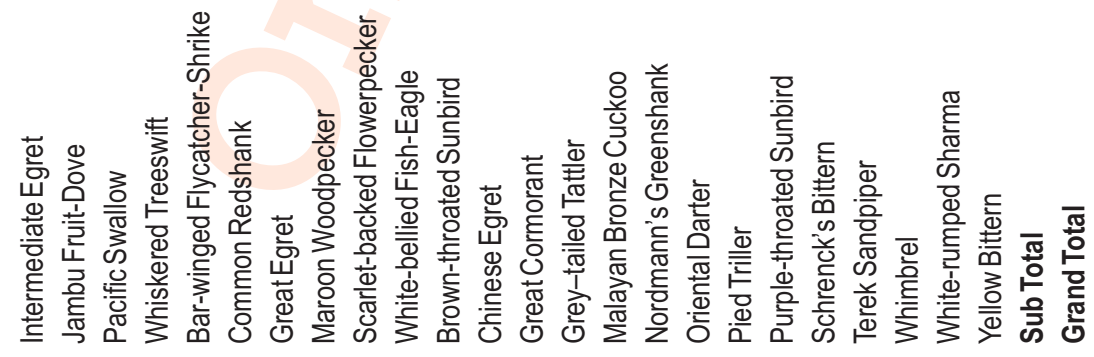

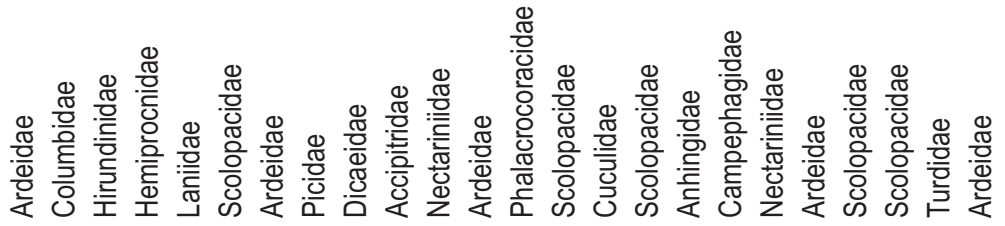

- Journal of Environmental Biology, Special issue, March 2020 
Table 3 : Diversity of bird species in three rivers of Marudu Bay Mangrove Forest Sabah, Malaysia

\begin{tabular}{llll}
\hline Index & Sungai bungon mati & Sungai supitan & Sungai sat \\
\hline Shannon's Diversity index $\mathrm{N}_{1}$ & 31.50 & 27.31 & 17.52 \\
Margalef's Richness index $\mathrm{R}_{1}$ & 7.42 & 7.69 & 5.67 \\
Pielou J Evenness indexE & 0.84 & 0.80 & 0.69 \\
\hline
\end{tabular}

Negelkereken et al., 2008), and water skaters (Lim et al., 2001). SBM harbors a higher number of bird species and diversity than the other two rivers, which could be due to the occurrence of shallow water depth and intertidal mudflats at various sites. The intertidal mudflat are exposed earlier as compared to the areas of SSU and SSA. Due to the earlier exposure of soft mud and shallow depth of water, wading birds prefer to use SBM areas for foraging. Moreover, the availability of adjacent landscape i.e. vegetated dry land area also provide suitable foraging, perching and nesting sites.

Based on the results of this study, such as recording of 69 bird species, it is evident that Marudu Bay mangrove forest is a suitable habitat for a variety of birds and it should be protected and used sustainably in order to protect and aid the survival of diverse aquatic and terrestrial avian species. Furthermore, this study also indicated that the occurrence of soft mud submerged by the tides of water, especially along river banks and at estuarine areas where water is shallow and rivers drain into the sea, i.e., the richness of food resources (fishes, crustaceans, gastropods, arthropods and worms) as well as dense vegetation are important driving factors affecting the richness and diversity of water birds together with the terrestrial or open country avifauna.

\section{References}

Aborn, D.A.: Abundance, density and diversity of neotropical migrants at the Lula Lake Land Trust, GA. Southeast Nat., 6, 293-304, (2007).

Aizpuru, M., F. Achard and F. Blasco: Global Assessment of Cover Change of the Mangrove Forests using satellite imagery at medium to high resolution. In: EEC Research Project 15017-199905 FIED ISPFR - Joint Research center, Ispra (2000).

Barbier, F.B. and M. Cox: An economic analysis of shrimp farm expansion and mangrove conversion in Thailand. Land. Econ., 80, 389-407 (2004).

Bibby, C.J., N.D. Burgess, D.A. Hill and S.H. Mustoe: Bird Census Techniques. $2^{\text {nd }}$ Edn., Academic Press, London (2000).

Black, W.M. and L.A. Brennan: The habitat concept in ornithology: Theory and applications. Curr. Ornithol., 11, 35-89 (1999).

Buckland, S.T., D.R. Anderson, K.P. Burnhamand and J.L. Laake: Distance Sampling: Estimating abundance of biological populations. Champman and Hall, London, ISBN- 10: 0198509278 (1993).

Cannicci, S., D. Burrows, S. Fratini, T.J. Smith III, J. Offenberg and F. Dahdouh-Guebas: Faunal impact on vegetation structure and ecosystem function in mangrove forests: A review. Aquat. Bot., 89, $168-200$ (2008)

Cueto, V.R. and J.L. de Casenave: Determinants of bird species richness: Role of climate and vegetation structure at a regional scale. J. Biogeogr., 26, 487-492 (1999).

DeSante, D.F., M.P. Nott and D.R. Kaschube: Monitoring, modeling and management: Why base avian monitoring on vital rates and how should it be done? In: Bird Conservation Implementation and Integration in the Americas (Eds.: C.J. Ralph and T.D. Rich) Illustrated, pp. 795-804 (2005).

Faridah-Hanum, I., K.A. Kudus and N.S. Saari: Plant diversity and biomass of Marudu Bay mangroves in Malaysia. Pak. J. Bot., 44, $151-156(2012)$.

Friess, A.D., K.W. Krauss, E.M. Horstman, T. Balke, T.J. Bouma, D. Gallin and E.L. Webb: Are all intertidal wetlands naturally created equal? Bottlenecks, threshold and knowledge gaps to mangrove and saltmarsh ecosystems. Bio. Revi., 87, 364-366 (2012).

Food and Agriculture Organization (FAO): The World's Mangroves, 1980 - 2005: A Thematic Study in the Framework of the Global Forest Resources Assessment 2005. FAO of United Nation Rome, Italy. Forestry Paper 153 (2007).

Giri, C., E. Ochieng, L.L. Tieszen, Z. Zhu, A. Singh, T. Loveland, J. Masek and N. Duke: Status and distribution of mangrove forests of the world using earth observation satellite data. Global Ecol. Biogeogr., 20, 154-159 (2011).

Githiru, M. and L. Lens: Demography of an afrotropical passerine in a highly fragmented landscape. Animal Conser., 9, 15-27 (2006).

Gregory, R.D., D.W. Gibbons and P.F. Donald: Bird census and survey techniques. In: Bird Ecology and Conservation (Eds.: W.J. Sutherland, I. Newton and R. Green). Oxford University Press, New York, USA. ISBN : 9780198520863 , pp. 371 (2004).

Han, K.L.: Mangrove fauna and their adaptations in the Kota Kinabalu wetland. Sab. Soc. J., 28, 15-22 (2011).

Hanum, F., A.L. Mohamad, K.R. Hakeem and M. Ozturk: Mangrove Ecosystems of Asia Status, Challenges and Management Strategies. Springer Verlag, ISBN 978-1-4614-8581-0, pp. 471 (2013).

Henderson, P.A. and R.M.H. Seaby: Community Analysis Package 4.0, Pisces Conservation Ltd, Lymington, UK (2007).

Kjerfve, B.: Manual for Investigation of Hydrological Processes in Mangrove Ecosystems. UNESCO/UNDP, Published in New Delhi, pages 79 (1990).

Kruitwagen, G., I. Nagelkerken, B.R. Lugendo, H.B. Pratap and E.W. Bonga: Influence of morphology and amphibious life-style on the feeding ecology of the mudskipper Periophthalmus argentilineatus. J. Fish Biol., 71, 39-52 (2007).

Leyequien, E., W.F. de Boer and V.M. Toledo: Bird community composition in a shaded coffee agro-ecological matrix in Puebla, Mexico: The effects of landscape heterogeneity at multiple spatial scales. Biotropica, 42, 236-245 (2010).

Li, Z.W.D. and T. Mundkur: Numbers and distribution of waterbirds and wetlands in the Asia-Pacific region: results of the Asian Waterbird Census: 2002-2004. Wetlands International, Kuala Lumpur, Malaysia (2007). 
Lim, K.K.P., D.H. Murphy, T. Morgany, N. Sviasothi, P.K.L. Ng, B.C. Soong, H.T.W. Tan, H.S. Tan and T.K. Tan: A Guide to the Mangroves of Singapore. Raffles Museum of Biodiversity Research, The National University of Singapore and The Singapore Science Centre, Singapore. $1^{\text {st }}$ Edn., Vol. 1, Animal Diversity (2001).

Manson, F.J., N.R. Loneragan, G.A. Skilleter and S.R. Phinn: An evaluation of the evidence for linkages between mangroves and fisheries: a synthesis of the literature and identification of research directions. Oceanogr. Mar. Biol. Annu. Rev., 43, 483 $513(2005)$.

Mineau, P., C.M. Downes, D.A. Kirk, E. Bayne and M. Csizy: Patterns of bird species abundance in relation to granular insecticides use in the Canadian Prairies. Eco. Sci., 12, 267-278 (2005).

McGraw-Hill, C.: Statistix 8.1 (Analytical Software, Tallahassee, Florida). Maurice/Thomas text, (2008) (ISBN: 0073402818).

Negelkerken, I., S.J.M. Blaber, S. Bouillon, P. Green, M. Haywood, L.G. Kiton, J.O. Meynecke, J. Pawlik, H.M. Penrose, A. Sasekumar and P.J. Somerfield: The habitat function of mangroves for terrestrial and marine fauna: Areview. Aquat. Bot., 89, 155-185 (2008).

Netto, S.A. and F. Gallucci: Meiofauna and macrofauna communities in a mangrove from the Island of Santa Catarina, South Brazil. Hydrobiologia, 505, 159-170 (2003).

Norhayati, A., M.N. Shukor, S. Julian and W.A. Wan Juliana: Mangrove flora and fauna of Klang Islands Mangrove Forest Reserves, Selangor, Malaysia. Malays J. Sci., 28, 275-288 (2009).
Noske, R.A.: The ecology of mangrove forest birds in Peninsular Malaysia. IBIS 137, 250-263(1995).

Rajpar, M.N. and M. Zakaria: Bird species abundance and their correlationship with microclimate and habitat variables at natural wetland reserve, Peninsular Malaysia. Int. J. Zool., 2011, 1-17 (2011).

Razali, N.M.: Power comparisons of Shapiro-Wilk, Kolmogorov-Smirnov, Lilliefors and Anderson-Darling test. J. Stat. Model Anal., 2, 21-33 (2011).

Sabah Forestry Department: Mangrove Forest Management and Restoration. Annual Report 2008. Chapter 23 (2008).

Sodhi, N.S., J.P.S. Choo, B.P.Y.H. Lee, K.C. Quek and and A.U. Kara.: Ecology of a mangrove forest bird community in Singapore. Raffles B. Zool., 45, 1-13 (1997).

Upadhyay, V.P., R. Ranjan and J.S. Singh: Human-mangrove conflicts: The way out. Curr. Sci., 83, 1328-1336 (2002).

Wan Juliana, W.A., A. Maimon, A, Norhayati, S.M. Razali, E. Mohd Fauzi, I. Izwahanie and M.N. Nurhanim: Mangrove Flora and Fauna of Manjung Riparian Reserves, Perak, Malaysia. Proceeding of Universiti Malaysia Terengganu (UMTAS 2011). International Annual Symposium on Life Science, Kuala Terengganu Malaysia; Empowering Science, Technology and Innovation Towards a Better Tomorrow LSP 39, pp. 412-417 (2011).

Zakaria, M., M.N. Rajpar and S.A. Sajap: Species diversity and feeding guilds of birds in Paya Indah Wetland Reserve, Peninsular Malaysia. Int. J. Zool. Res., 5, 86-100 (2009). 